\title{
PNNL Results from 2009 Silene Criticality Accident Dosimeter Intercomparison Exercise
}

\author{
R. L. Hill \\ M. M. Conrady
}

June 2010

\section{Pacific Northwest}

NATIONAL LABORATORY

Proudly Operated by Battelle Since 1965 


\section{DISCLAIMER}

This report was prepared as an account of work sponsored by an agency of the United States Government. Neither the United States Government nor any agency thereof, nor Battelle Memorial Institute, nor any of their employees, makes any warranty, express or implied, or assumes any legal liability or responsibility for the accuracy, completeness, or usefulness of any information, apparatus, product, or process disclosed, or represents that its use would not infringe privately owned rights. Reference herein to any specific commercial product, process, or service by trade name, trademark, manufacturer, or otherwise does not necessarily constitute or imply its endorsement, recommendation, or favoring by the United States Government or any agency thereof, or Battelle Memorial Institute. The views and opinions of authors expressed herein do not necessarily state or reflect those of the United States Government or any agency thereof.

$$
\begin{gathered}
\text { PACIFIC NORTHWEST NATIONAL LABORATORY } \\
\text { operated by } \\
\text { BATTELLE } \\
\text { for the } \\
\text { UNITED STATES DEPARTMENT OF ENERGY } \\
\text { under Contract DE-AC05-76RLO1830 } \\
\text { Printed in the United States of America } \\
\text { Available to DOE and DOE contractors from the } \\
\text { Office of Scientific and Technical Information, } \\
\text { P.O. Box 62, Oak Ridge, TN 37831-0062; } \\
\text { ph: (865) 576-8401 } \\
\text { fax: (865) 576-5728 } \\
\text { email: reports@adonis.osti.gov }
\end{gathered}
$$

Available to the public from the National Technical Information Service,

U.S. Department of Commerce, 5285 Port Royal Rd., Springfield, VA 22161

$$
\text { ph: (800) 553-6847 }
$$$$
\text { fax: (703) 605-6900 }
$$

email: orders@ntis.fedworld.gov

online ordering: http://www.ntis.gov/ordering.htm

This document was printed on recycled paper.

$(9 / 2003)$ 


\section{PNNL Results from 2009 Silene Criticality Accident Dosimeter} Intercomparison Exercise

\section{Approval Signatures:}

Authors:

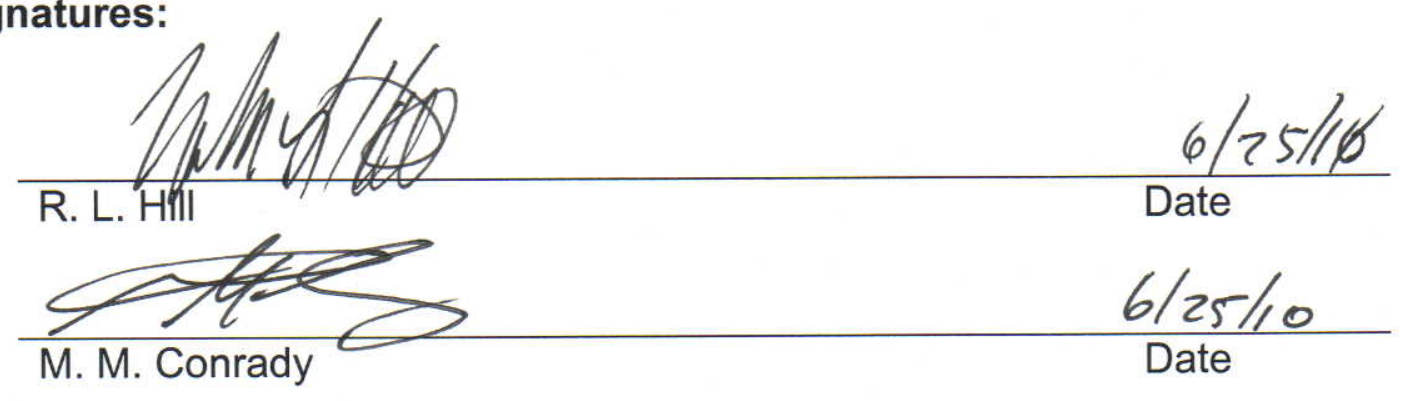

Peer

Reviewed by:

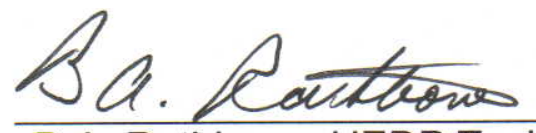

B.A. Rathbone, HEDP Technical Manager

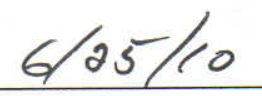

Approved by:

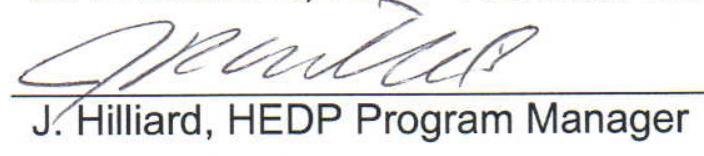

Date

Approved by:

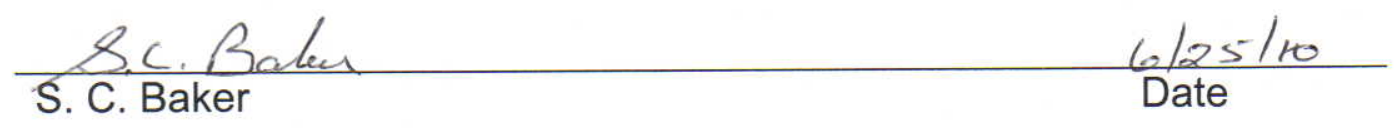


PNNL Results from 2009 Silene Criticality Accident Dosimeter Intercomparison Exercise

Issued: June $2010 \quad$ PNNL-19503

Revision: 0

Page iii of v

\section{ABSTRACT}

This document reports the results of testing of the Hanford Personnel Nuclear Accident Dosimeter (PNAD) during a criticality accident dosimeter intercomparison exercise at the CEA Valduc Center on October 13, 14, and 15, 2009.

KEY WORDS: personnel nuclear accident dosimeter; PNAD; Silene Reactor; intercomparison. 
PNNL Results from 2009 Silene Criticality Accident Dosimeter Intercomparison Exercise

Issued: June $2010 \quad$ PNNL-19503

Revision: 0

Page iv of $v$

TABLE OF CONTENTS

Abstract iii

Table of Contents. iv

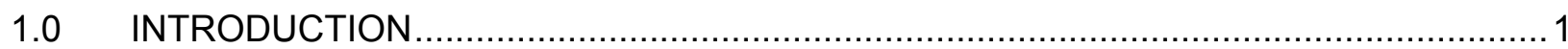

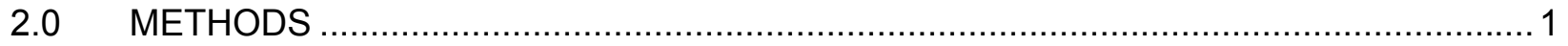

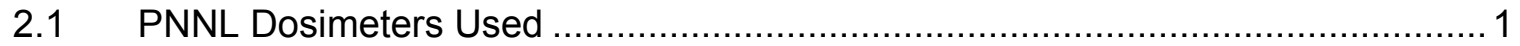

$2.2 \quad$ Silene Reactor at the Valduc Center ............................................................ 2

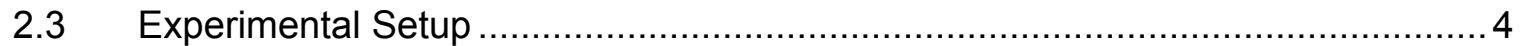

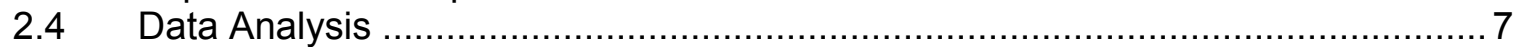

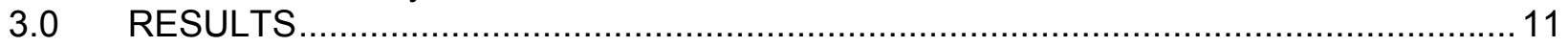

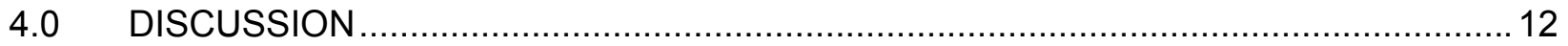

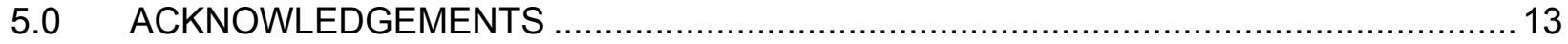

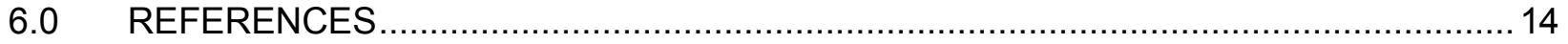

\section{LIST OF TABLES}

Table 1. Materials and Approximate Dimensions of the PNAD Components .......................... 2

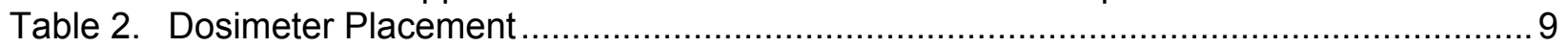

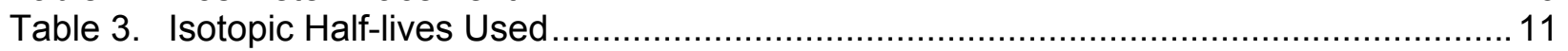

Table 4. Activity to Fluence Factors for Hanford PNAD ............................................. 11

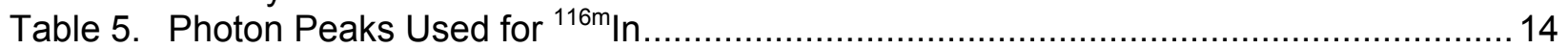

Table 6. Summary of Estimated Doses and Number of Fissions for Hanford PNAD ............... 15

Table 7. Results of Three Experimental Irradiations at the Silene Reactor............................15

Table 8. Fraction of Neutron Dose Contribution .......................................................... 16

Table 9. Number of Fissions For Each Irradiation Experiment...................................... 17

Table 10. Average Neutron to Gamma Dose Ratios .................................................... 17

Table 11. Preliminary PNAD Neutron Dose Related to Orientation ...................................... 17

\section{LIST OF FIGURES}

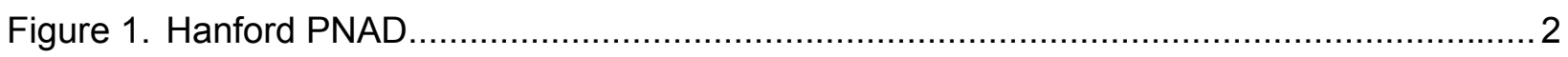

Figure 2. First irradiation with dosimeters on phantom at $2 \mathrm{~m}$ from lead-shield

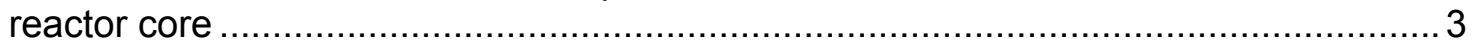

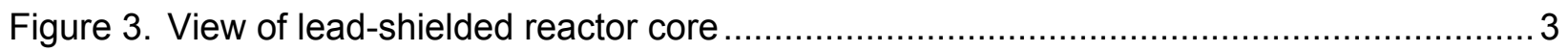

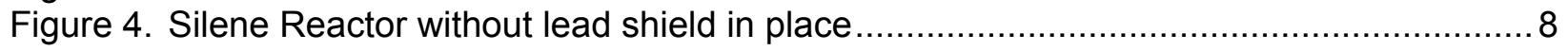

Figure 5. Positioning of dosimeters on phantom front facing reactor core ............................. 9

Figure 6. Positioning of dosimeters on phantom front (F), side (S), and back (B).................. 10

Figure 7. Plot of Cd-113 (n, total) Cross Section ............................................................ 14 


\section{PNNL Personnel Nuclear Accident Dosimeter Results from 2009 Intercomparison Exercise at the Silene Reactor, October 2009}

\subsection{INTRODUCTION}

Pacific Northwest National Laboratory (PNNL) participated in a criticality accident dosimeter intercomparison exercise at the Commissariat a' Energie Atomique (CEA) Valduc Center near Dijon, France on October 9-20, 2009. The intercomparison exercise was funded by the U.S. Department of Energy, Nuclear Criticality Safety Program, with Lawrence Livermore National Laboratory as the lead Laboratory. PNNL was one of five invited DOE Laboratory participants. The other participating Laboratories were: Lawrence Livermore National Laboratory, Los Alamos National Laboratory, Savannah River Site, and the Y-12 National Security Complex at Oak Ridge.

Similar intercomparison studies of the PNNL personnel nuclear accident dosimeter (PNAD) had not been done since the early to mid-1980s. The goal of PNNL's participation in the intercomparison exercise was to test and validate the procedures and algorithm currently used for the PNADs at PNNL.

\subsection{METHODS}

\subsection{PNNL Dosimeters Used}

For this exercise, the following Hanford dosimeters were used: PNAD, Hanford Standard Dosimeter (HSD), and Hanford Combination Neutron Dosimeters (HCND). This document reports on the results of the PNAD study only. Results from the other dosimeters and further analysis of the data are planned for a subsequent report.

\subsubsection{PNAD}

The Hanford PNAD is based on the outer dosimeter packet of the Hanford Fixed Nuclear Accident Dosimeter design and the PNAD used at the Los Alamos National Laboratory (LANL) (PNNL, 2010). The components of the Hanford PNAD are listed in Table 1 and illustrated in Figure 1-A and 1-B. Figure 1-A shows the Hanford PNAD that currently is in use. The PNAD shown in Figure 1-B shows the design used for the experiments at the Valduc center. The same specifications apply to the PNAD used in these experiments, except that, (1) the outer Plexiglas encasement was held together by nylon screws for easy disassembly instead of the glue used on the regular Hanford PNAD, (2), the sulfur pellet was put into heat-sealed plastic to facilitate easy handling when counting, as shown in Figure 1-B, and (3) two TLD-700 chips were added to this version of the PNAD instead of the one used in the currently used Hanford PNAD to improve counting statistics. 


\section{PNNL Personnel Nuclear Accident Dosimeter Results from 2009 Intercomparison Exercise at the Silene Reactor, October 2009}

Table 1. Materials and Approximate Dimensions of the PNAD Components

\begin{tabular}{|c|c|c|c|}
\hline \hline Position in PNAD & Description & Diameter (cm) & Thickness (cm) $^{(\mathbf{c})}$ \\
\hline 1 & $\begin{array}{c}\text { Indium (Cd } \\
\text { shielded) }\end{array}$ & 1.27 & 0.0127 \\
\hline 2 & Sulfur Pellet & 1.27 & 0.292 \\
\hline 3 & Indium (Bare) & 1.14 & 0.0127 \\
\hline 4 & $\begin{array}{c}\text { Copper (Cd } \\
\text { shielded) }\end{array}$ & 1.27 & 0.0127 \\
\hline- & TLD-700 Chip & $0.32 \times 0.32^{(\mathrm{b})}$ & 0.089 \\
\hline
\end{tabular}

(a) The cadmium (Cd) shields covering the indium and copper foils are $0.051 \mathrm{~cm}$ thick.

(b) The TLD-700 chip measures 0.32 by $0.32 \mathrm{~cm}$ square by $0.089 \mathrm{~cm}$ thick.

(c) All dimensions are nominal.

A.

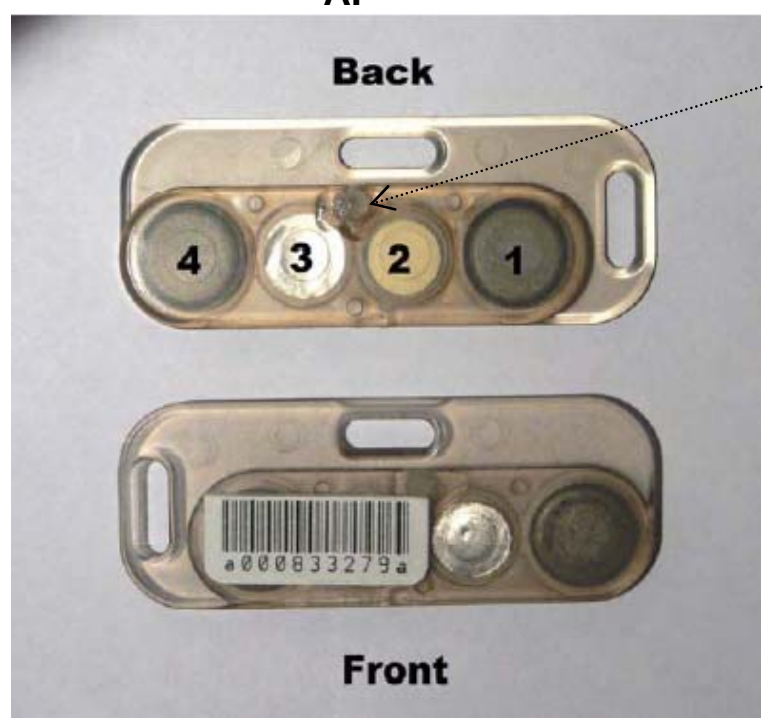

B.

TLD Chip(s)

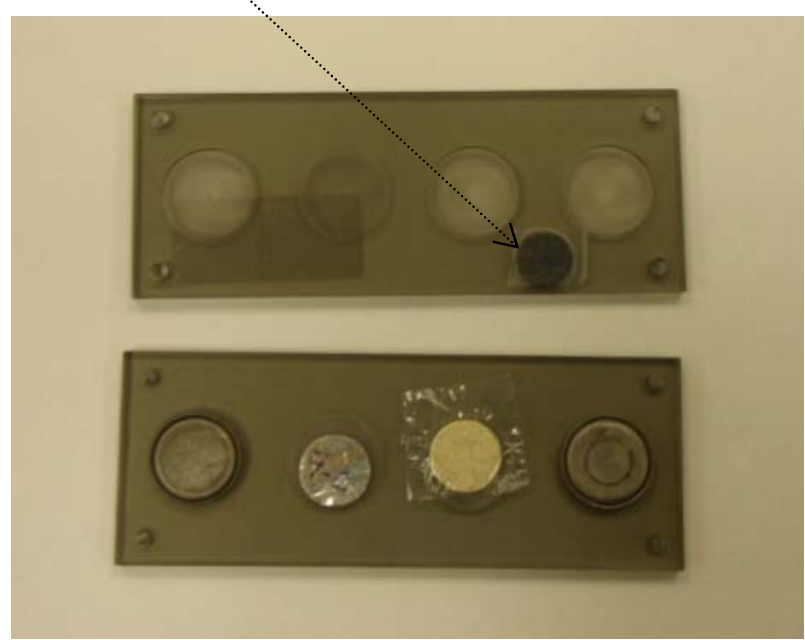

Figure 1. Hanford PNAD

\subsection{Silene Reactor at the Valduc Center}

The Silene reactor is located at the CEA Valduc Center outside of Dijon, France. The reactor consists of uranium nitrate and was operated in the pulse mode. For the first experimental irradiation done on October 13,2009, the reactor was operated with a $10 \mathrm{~cm}$ lead shield in place as shown in Figures 2 and 3, and bare (without the lead shield) on the second and third experiments (October 14 and 15, 2009, respectively) as shown in Figure 4. 


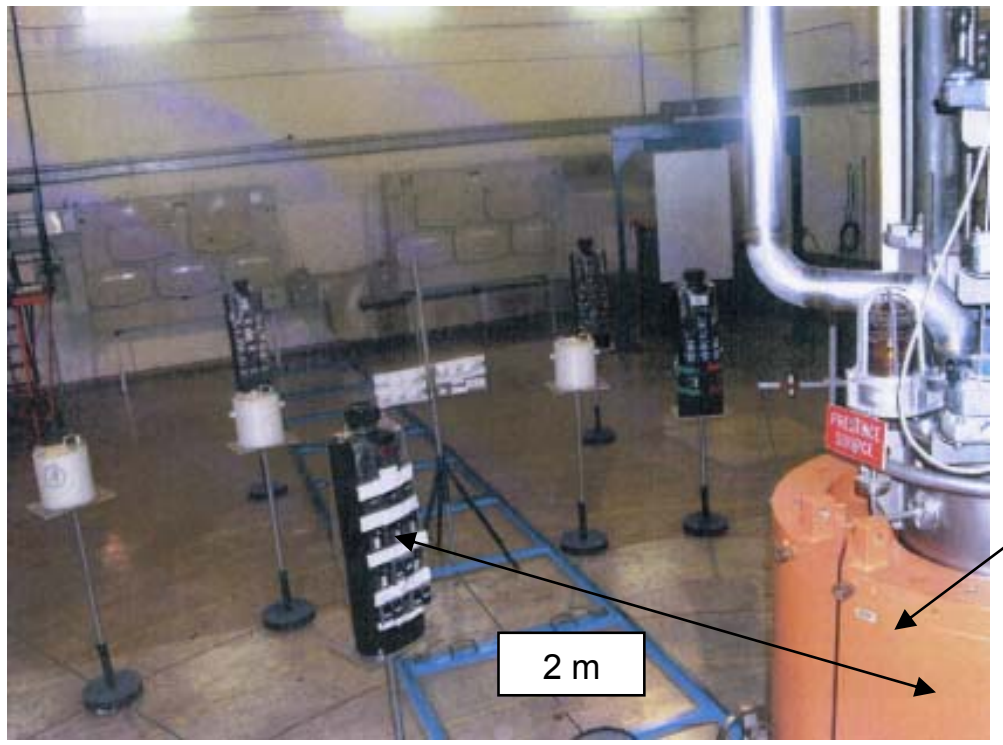

Figure 2. First irradiation with dosimeters on phantom at $2 \mathrm{~m}$ from lead-shielded reactor core (photo from CEA/VA/DRMN/SRNC DO 1077 Report)

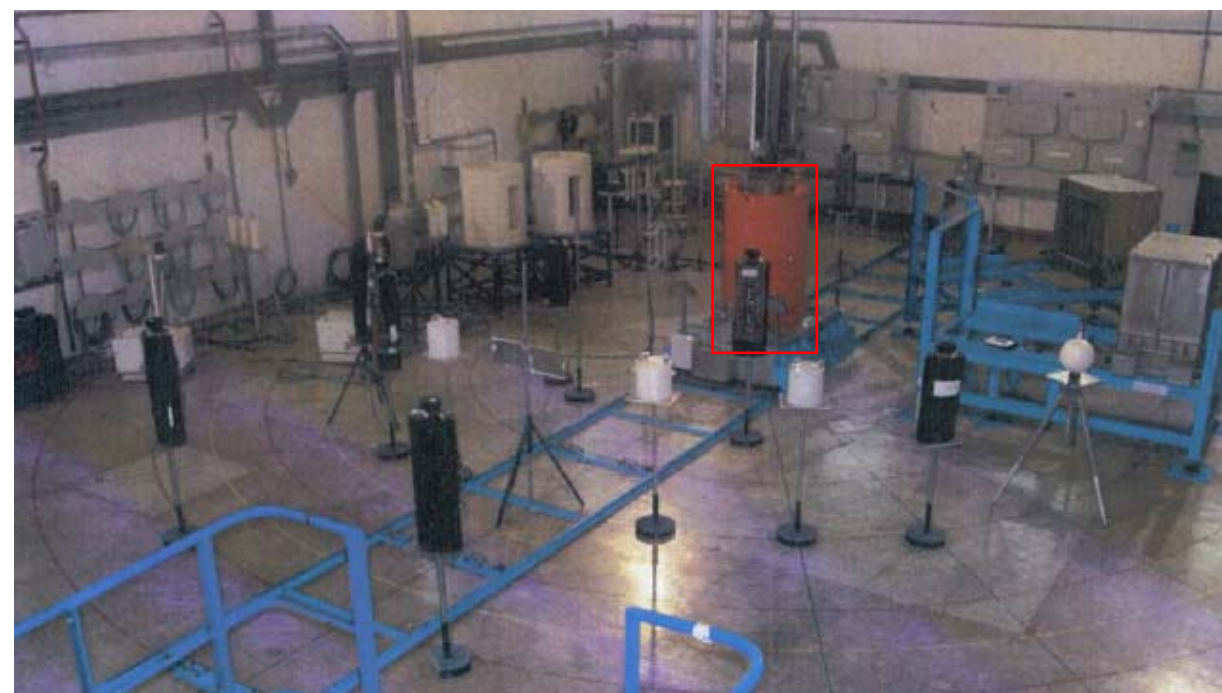

Figure 3. View of lead-shielded reactor core (photo from CEA/VA/DRMN/SRNC DO 1077 Report) 


\section{PNNL Personnel Nuclear Accident Dosimeter Results from 2009 Intercomparison Exercise at the Silene Reactor, October 2009}

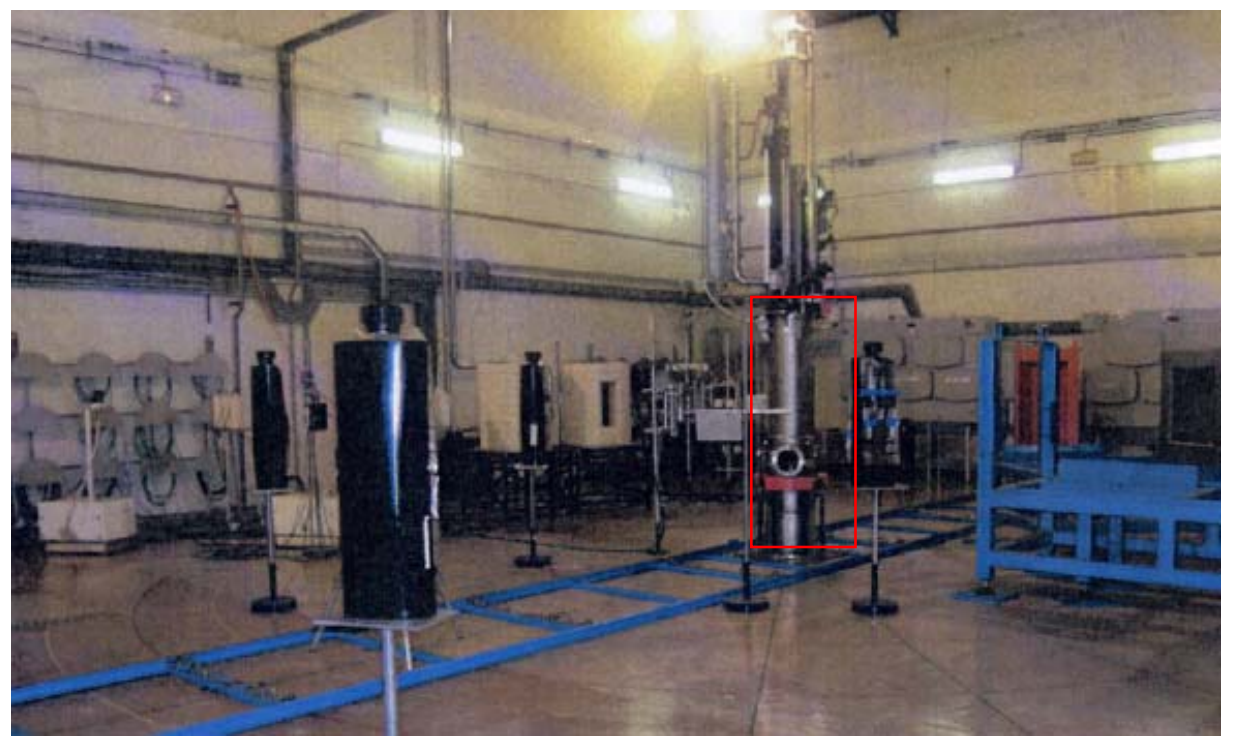

Figure 4. Silene Reactor without lead shield in place (photo from CEA/VA/DRMN/SRNC DO 1078 Report)

\subsection{Experimental Setup}

\subsubsection{Irradiations}

The first experimental irradiation was done on October 13, 2009. The PNADs and other dosimeters were placed on phantoms that were $60 \mathrm{~cm}$ tall, $20 \mathrm{~cm}$ by $30 \mathrm{~cm}$ elliptical phantoms that were filled with water. The phantoms stood on aluminum stands at a height of $80.5 \mathrm{~cm}$ and were placed such that the dosimeters would be 2 meters from the center of the reactor. The dosimeters were placed in a plastic holder provided by the Valduc staff and placed on the front of the phantom facing the reactor core, as shown in Figure 5. The number and type of dosimeters used are summarized in Table 2. For Experiment 1, the lead shield was placed around the reactor as shown in Figures 2 and 3. For this experiment, other French agencies also had dosimeters and equipment installed during the irradiation.

After each irradiation, the Valduc staff held the PNADs and dosimeters for 3-4 hours to ensure that the dose to the individuals handling them had decayed enough so that they would be within their organizational radiation limits for handling.

For Experiment 2, the set up was similar to those of Experiment 1 with the following exceptions: (1) the lead shield on the reactor was removed (Figure 4), and (2) only the five DOE Laboratories participated in this exercise.

For Experiment 3, the reactor set up was similar to that used in Experiment 2 but a higher pulse was used. The phantoms and dosimeters were placed at 6 meters for this experiment in order that the foils in the PNADs would have enough time to decay and still be handled and counted on the same day as the irradiation. Also, the PNADs and dosimeters were placed on the phantom with the phantom facing either front, sideways, or with its back facing the reactor (Figure 6). A free-in-air PNAD was also used. 
PNNL Personnel Nuclear Accident Dosimeter Results from 2009 Intercomparison Exercise at the Silene Reactor, October 2009

Table 2. Dosimeter Placement

\begin{tabular}{||c|c|c|c|}
\hline Experiment Number & $\begin{array}{c}\text { Distance } \\
(\mathbf{m})\end{array}$ & Location Description & $\begin{array}{c}\text { Dosimeter } \\
\text { Type }\end{array}$ \\
\hline $\begin{array}{c}1 \\
\text { Lead Shielded Pulse }\end{array}$ & 2 & Front of Phantom & $\begin{array}{c}5 \text { PNADs } \\
3 \text { HSDs } \\
3 \text { HCNDs }\end{array}$ \\
\hline 2 & 2 & Front of Phantom & $\begin{array}{c}5 \text { PNADs } \\
3 \text { HSDs } \\
3 \text { HCNDs }\end{array}$ \\
\hline $\begin{array}{c}\text { Bare Low-Power Pulse } \\
\text { Bare High-Power Pulse }\end{array}$ & 6 & $\begin{array}{l}\text { 2 PNADs - Phantom Front } \\
\text { 2 PNADS - Phantom Side } \\
\text { 2 PNADS - Phantom Back } \\
\text { 1 PNAD - Free in Air }\end{array}$ & $\begin{array}{c}7 \text { PNADs } \\
2 \text { HSDs } \\
2 \text { HCNDs }\end{array}$ \\
\hline
\end{tabular}

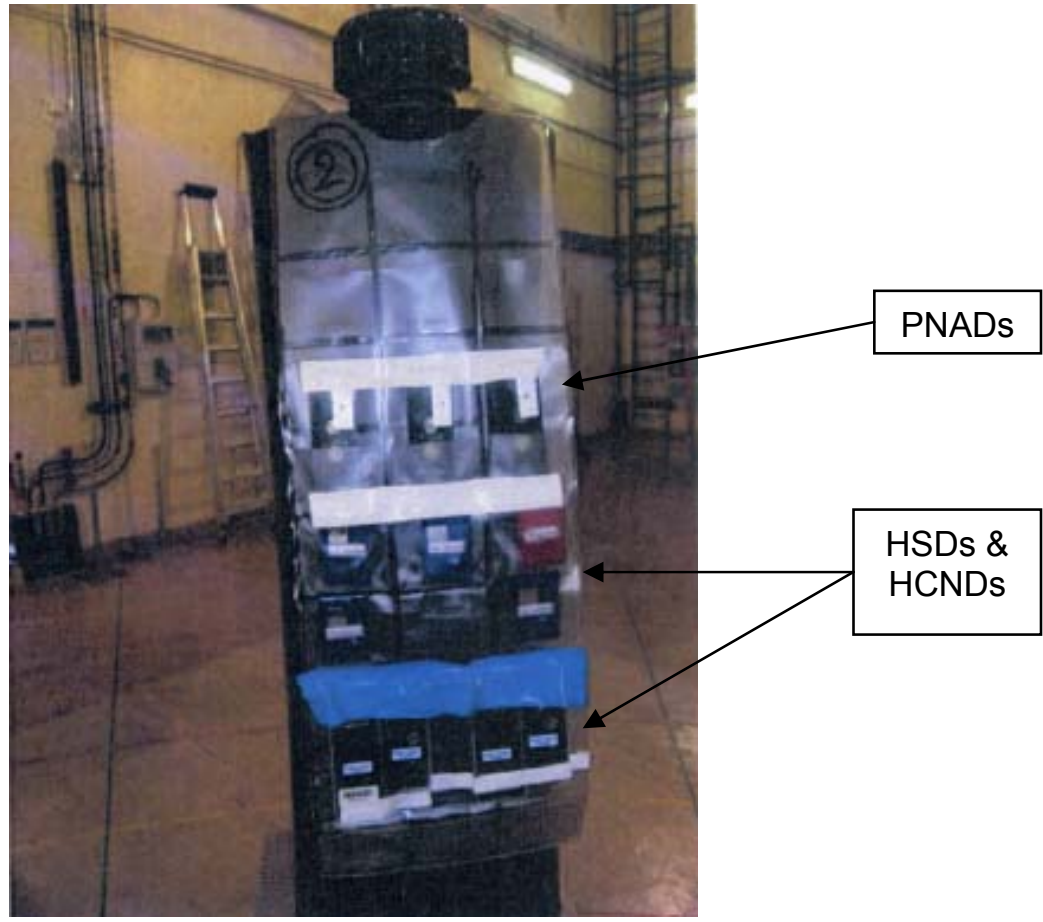

Figure 5. Positioning of dosimeters on phantom front facing reactor core (photo from CEA/VA/DRMN/SRNC DO 1078 Report) 


\section{PNNL Personnel Nuclear Accident Dosimeter Results from 2009 Intercomparison Exercise at the Silene Reactor, October 2009}

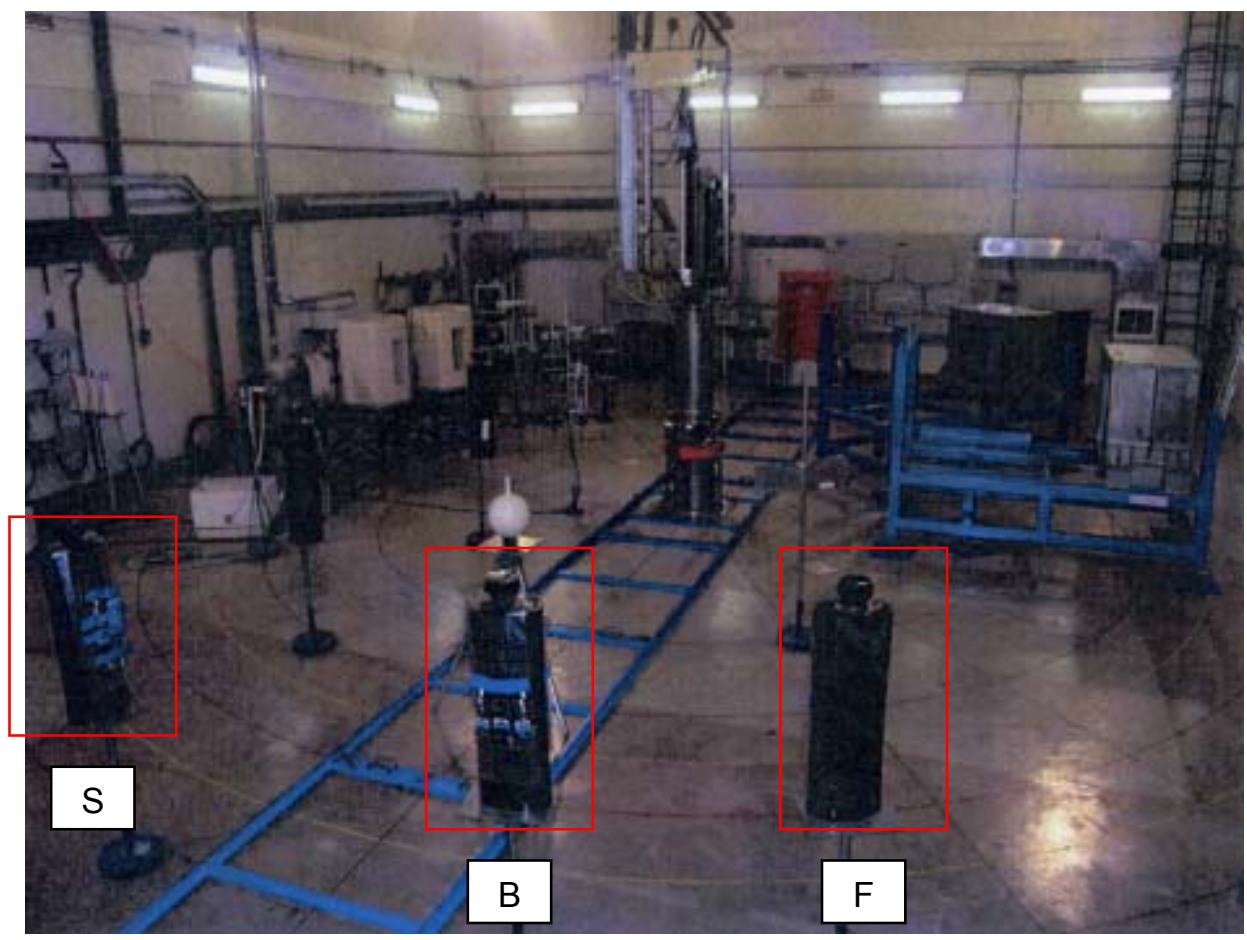

Figure 6. Positioning of dosimeters on phantom front (F), side (S), and back (B) (photo from CEA/VA/DRMN/SRNC DO 1076 Report)

\subsubsection{Counting Protocols}

As the lead DOE Laboratory, LLNL offered to perform the counting of the foils and sulfur pellets. The indium and copper foils were measured using an electronically cooled highpurity germanium (HPGe) detector. The detector was calibrated for the average Hanford PNAD foil dimensions (Table 1) using the Canberra Industries ISOSC ${ }^{\circledR}$ technology. The indium foils were counted with a minimum of 2,000 counts in the $363 \mathrm{keV}$ peak region and the copper foils were counted with a minimum of 500 counts in the $511 \mathrm{keV}$ peak region. In some cases where total counting time was limited, the counting on some copper foils may have been terminated before 500 counts were reached.

No capabilities were available at the Valduc Center for melting the sulfur pellets prior to counting. Therefore, the Hanford sulfur pellets were counted whole on a scalar system by LLNL while still in the heat-sealed thin plastic. They were placed into a stainless steel planchet, covered with 0.25 mil Mylar and counted for 10 minutes using a Ludlum Model $3030 E$ scalar with a Ludlum 43-10-1 alpha/beta probe in a lead cave provide by the Valduc Center. The average mass of the Hanford sulfur pellets used was $0.449 \mathrm{~g}$ and were $99.9 \%$ pure sulfur. The counts were background corrected and used detector efficiencies ranging from $43.8 \%$ to $47.8 \%$, depending on the individual counting system used. We were not able to ship the exposed sulfur pellets. Therefore, the onsite count data was all that was available for the analysis.

The TLD chips in the PNAD were used to obtain the dose from gammas, $\left(D_{\text {gamma }}\right)$. The TLDs from the PNADs were brought back to PNNL for analysis. They were read on a 


\section{PNNL Personnel Nuclear Accident Dosimeter Results from 2009 Intercomparison Exercise at the Silene Reactor, October 2009}

Harshaw Model 5500 TLD reader using a standard process for PNAD TLD. Adjustments in the gain were necessary for reading these TLDs due to the high level of delivered dose. Corrections for variations in individual chip sensitivity and for supralinearity were applied to the readings and the average of the two TLD chips from a given PNAD was reported.

\subsection{Data Analysis}

The data analysis approach used for the Hanford PNADS is discussed below. Half-life values used were taken from Nuclides and Isotopes $15^{\text {th }}$ Edition, General Electric Co. and KAPL, Inc., 1996 (Table 3).

Table 3. Isotopic Half-lives Used

\begin{tabular}{||c|c|c|c||}
\hline Isotope & $\begin{array}{c}\text { Half-Life } \\
\text { (units) }\end{array}$ & $\begin{array}{c}\text { Half-Life } \\
\text { (minutes) }\end{array}$ & Lambda \\
\hline \hline Cu-64 & $12.701(\mathrm{~h})$ & 762.06 & $9.10 \mathrm{E}-04$ \\
\hline S-35 & $87.2(\mathrm{~d})$ & 125568 & $5.52 \mathrm{E}-06$ \\
\hline In-116m & --- & 54.2 & $1.28 \mathrm{E}-02$ \\
\hline In-115m & $4.486(\mathrm{~h})$ & 269.16 & $2.58 \mathrm{E}-03$ \\
\hline
\end{tabular}

The dose from neutrons, $D_{\text {neutron, }}$ was calculated from the foil and sulfur pellet counting data. Table 4 provides the Hanford PNAD element information for the five neutron energy ranges evaluated.

Table 4. Activity to Fluence Factors for Hanford PNAD

\begin{tabular}{|c|c|c|c|c|c|c|}
\hline $\begin{array}{l}\text { Neutron } \\
\text { Energy } \\
\text { Range } \\
\end{array}$ & $\begin{array}{c}\text { Foil/Pellet } \\
\text { Combination }\end{array}$ & $\begin{array}{l}\text { Decay } \\
\text { Constant } \\
\lambda\left(\min ^{-1}\right) \\
\end{array}$ & $\begin{array}{c}\text { Target } \\
\text { Atom } \\
\text { Abundance } \\
\end{array}$ & $\begin{array}{l}\text { Foil Atomic } \\
\text { Weight } \\
\text { (AMU) }\end{array}$ & $\begin{array}{l}\text { Cross } \\
\text { Section } \\
\text { (barns) }\end{array}$ & $\underset{\left(\min -g ~ c m^{-1}\right)}{C_{x}}$ \\
\hline $\begin{array}{c}\text { Thermal to } \\
0.4 \mathrm{eV}\end{array}$ & $\begin{array}{c}\text { In-116m } \\
\text { (Bare-Cd) }\end{array}$ & $1.28 \mathrm{E}-02$ & 0.957 & 114.82 & 161 & $9.8 \mathrm{E}+01$ \\
\hline $\begin{array}{c}\text { Epithermal } \\
0.4 \mathrm{eV} \text { to } 2 \\
\mathrm{eV}\end{array}$ & In-116m(Cd) & $1.28 \mathrm{E}-02$ & 0.957 & 114.82 & 2600 & 6.00 \\
\hline $\begin{array}{c}2 \mathrm{eV} \text { to } 0.5 \\
\mathrm{MeV}\end{array}$ & $\mathrm{Cu}(\mathrm{Cd})$ & $9.094 \mathrm{E}-04$ & 0.692 & 63.54 & 0.341 & $4.92 \mathrm{E}+05$ \\
\hline $\begin{array}{c}\text { Above } 1.2 \\
\text { MeV }\end{array}$ & $\begin{array}{c}\ln (\mathrm{Cd}) \\
(\ln -115 \mathrm{~m})\end{array}$ & $2.575 \mathrm{E}-03$ & 0.957 & 114.82 & 0.188 & $4.11 \mathrm{E}+05$ \\
\hline $\begin{array}{c}\text { Above } 2.9 \\
\text { MeV }\end{array}$ & Sulfur & 3.368E-05 & 1.00 & 32.064 & 0.238 & $6.98 \mathrm{E}+06$ \\
\hline
\end{tabular}

$$
C_{X}=\left(\frac{1}{\lambda n \sigma}\right)
$$

where $\quad \mathrm{C}_{\mathrm{X}}=$ abundance correction factor

$\lambda=$ decay constant $\left(\min ^{-1}\right)$ 


\section{PNNL Personnel Nuclear Accident Dosimeter Results from 2009 Intercomparison Exercise at the Silene Reactor, October 2009}

$\mathrm{n}=$ number of target atoms $\mathrm{g}^{-1}$ in foil/pellet

$\sigma=$ activation cross section (barns).

\subsubsection{Calculation of Number of Fissions}

The number of fissions was calculated for each energy group based off of the calculated neutron fluence $(\Phi)$. For each energy group, the fluence is calculated using the formula outlined in the PNNL procedure for processing PNAD results. There are two different options that could have been used to calculate the number of fissions, but both are based off of the fluence. They are:

- Estimation of the neutron flux $(\varphi)$ for each group from dividing each of the energy group fluences by the length of the experiment irradiation.

- Fission rate method.

Several months after the experiments took place, the Valduc Staff provided the time duration of each experiment, also called the excursion time. The excursion times were 8 seconds, 9 seconds, and 5 seconds for the first, second, and third experiments, respectively. An estimate of the neutron flux $(\varphi)$ for each group was obtained by dividing each of the energy group fluences by the length of the experimental irradiation. The downside with this method is, 1) for most accident scenarios, the length of the excursion will not be known, and 2) for an intercomparison, the length of time will likely not be provided at the time of the experiment. The advantage of knowing the experiment time and using the flux method is that it provides both the total number of fissions and the rate of fission. For completeness, both calculation options are shown, but only the calculation for the total number of fissions was used for reporting the total number of fissions.

\section{Total Number of Fissions:}

Neutrons_Emitted $_{i}=\Phi_{i} * 4 \pi \mathrm{r}^{2}$

TNOF $=\frac{\sum_{i=1}^{n} \text { Neutrons__Emitted }_{i}}{\text { Average_Number_ofNeutrons_per_Fission_for_U235 }}$

Fission Rate Method:

$\phi_{i}=\frac{\Phi_{i}}{\text { excursion_time }}$

$\phi_{i}=\frac{S_{0}}{4 \pi r^{2}}$

$S_{0_{i}}=\frac{\Phi_{i}}{\text { excursion_time }} * 4 \pi r^{2}$ 


$$
\begin{aligned}
& \mathrm{ROF}=\frac{\sum_{i=1}^{n} S_{0_{i}}}{\text { Average_Number_of_Neutrons_per_Fission_for_U235 }} \\
& \mathrm{TNOF}=\frac{\sum_{i=1}^{n} S_{0_{i}}}{\text { Average_Number_of_Neutrons_per_Fission_for_U235 }} * \text { excursion_time }
\end{aligned}
$$

Where:

$$
\begin{aligned}
& S_{0} \quad=\text { source strength (neutrons-second }{ }^{-1} \text { ) } \\
& \varphi \quad=\text { neutron flux (neutrons }-\mathrm{cm}^{-2} \text {-second }{ }^{-1} \text { ) } \\
& \text { ROF } \quad=\text { rate of fission (fissions-second }{ }^{-1} \text { ) } \\
& \text { TNOF } \quad=\text { total number of fissions } \\
& \Phi=\text { neutron fluence (neutrons }-\mathrm{cm}^{-2} \text { ) } \\
& \text { excursion_time }=\text { (seconds) } \\
& r \quad=\text { radius }\left(\mathrm{cm}^{2}\right)
\end{aligned}
$$

Average_Number_of_Neutrons_Emitted_per_Fission $=2.47$, "Distributions of Fission Neutron Numbers", Phys. Rev. $\overline{108}, 783$ (1957), by John Terrell

\subsubsection{Indium-116m Activity Determination}

LLNL defined a pre-set number of photon energy peaks (Table 5) for determining the total activity of ${ }^{116 \mathrm{~m}} \mathrm{In}$. In the analysis report provided for every counted indium foil, each photopeak had an estimate of total activity for the sample associated with it. Any of the activity values provided for any one of the photopeaks could have been used for the total sample activity. PNNL chose to take each photopeak activity and normalize it to the total yield. This method was chosen to provide a better estimate of the total sample activity, based on a larger sample population.

Table 5. Photon Peaks Used for ${ }^{116 \mathrm{~m}} \mathrm{In}$

\begin{tabular}{|c|c|}
\hline Photon Energy (keV) & Photon Yield (\%) \\
\hline 416.86 & 27.7 \\
\hline 818.72 & 11.5 \\
\hline 1097.33 & 56.2 \\
\hline 1293.56 & 84.4 \\
\hline 1507.67 & 10.0 \\
\hline 2112.31 & 15.5 \\
\hline
\end{tabular}




\section{PNNL Personnel Nuclear Accident Dosimeter Results from 2009 Intercomparison Exercise at the Silene Reactor, October 2009}

Total_Photon_Yield $=\sum_{i}^{n}{\text { Photon_ } \text { Yield }_{i}}$

Normalized_Activity $_{i}=$ Activity $_{i} *\left(\frac{\text { Photon_Yield }}{\text { Atal_Photon_Yield }_{\text {Tot }}}\right)$

Total_Activity $=\sum_{i}^{n}$ Normalized _ Activity $_{i}$

\subsubsection{Activity for Energy Group Above $1.2 \mathrm{MeV}$}

For Experiments 1 and 2, the calculation for activity and number of fissions for the energy group above $1.2 \mathrm{MeV}$ was calculated using data provided from photon data from bare indium foils using the results of the In-115m activity. In some cases, there was a backlog of foils from five different DOE Laboratories to be counted on the single counting system, which lead to decay of some of the short-lived radionuclides before the foils could be counted. For Experiment 3, this was the case for several PNNL foils where no data was obtained for ${ }^{115 \mathrm{~m}} \mathrm{In}$ using bare foils since it had decayed before the foils were counted. As described in the PNNL procedure for processing PNAD results, it is acceptable to use ${ }^{115 \mathrm{~m}}$ In data from cadmium covered indium foils as this energy is well above the neutron cutoff energy for cadmium. Figure 7 shows the total neutron cross section for ${ }^{113} \mathrm{Cd}$, which has the largest neutron cross section of all the stable cadmium isotopes. This figure shows that there is a very small cadmium cross section at energies around $1.2 \mathrm{MeV}$, thus allowing the use of either cadmium covered indium foils or bare indium foils at this energy.

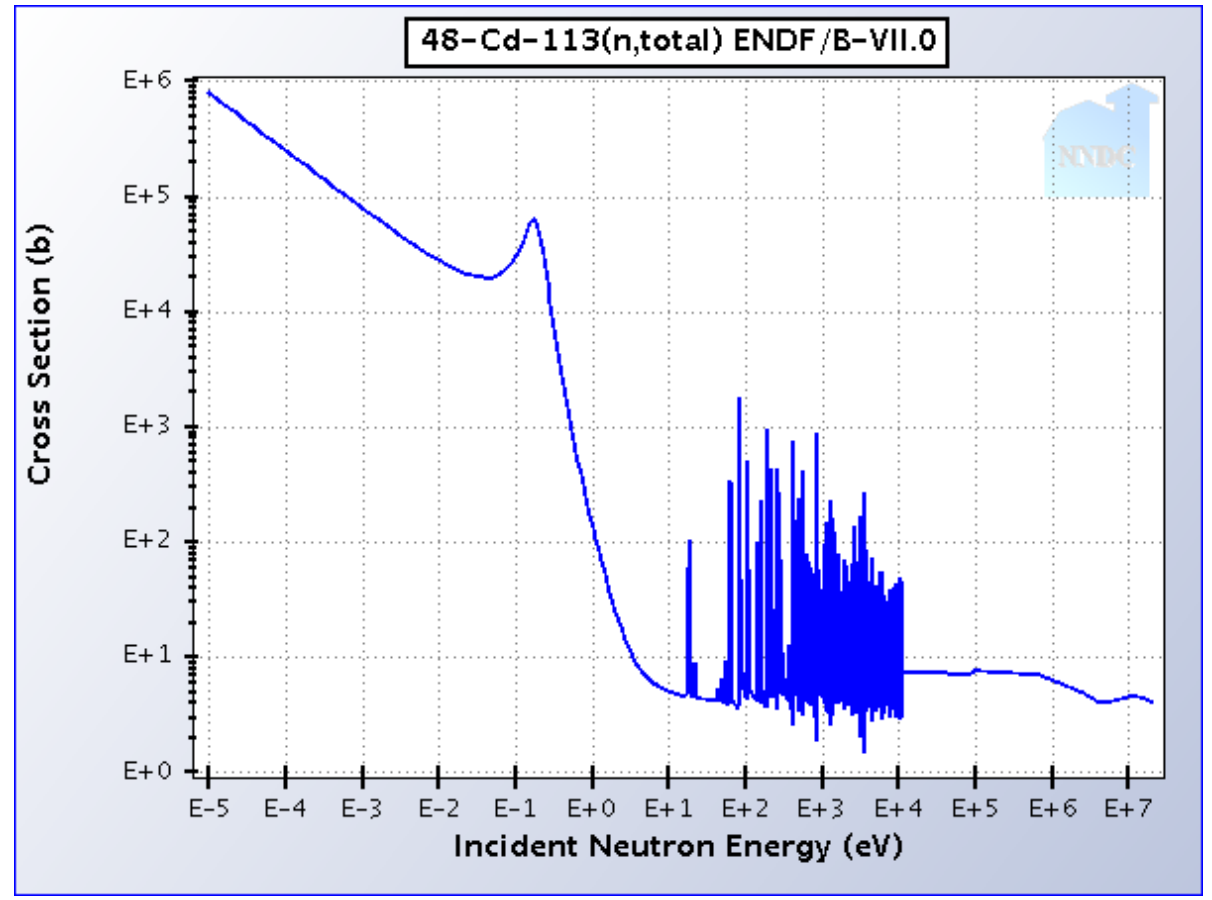

Figure 7. Plot of Cd-113 ( $\mathrm{n}$, total) Cross Section

(Obtained from Sigma Plotting tool at National Nuclear Data Center, www.nndc.bnl.gov) 


\section{PNNL Personnel Nuclear Accident Dosimeter Results from 2009 Intercomparison Exercise at the Silene Reactor, October 2009}

Revision: 0

Page 11 of 14

\subsection{RESULTS}

The dose from neutrons $\left(D_{\text {neutron }}\right)$ and gammas $\left(D_{\text {gamma }}\right)$ was summed to get the total dose for each PNAD used in each of the three irradiation experiments. A summary of the resulting doses and calculated number of fissions for each of the three experimental irradiations is given in Table 6. These doses represent the average of five PNADs for Experiments 1 and 2 and two PNADs facing the reactor in Experiment 3.

Table 6. Summary of Estimated Doses and Number of Fissions for Hanford PNAD

\begin{tabular}{|c|c|c|c||}
\hline \hline Expt. & \# Fissions & Dose $_{\text {neutron }}(\mathrm{rad})$ & Dose $_{\text {gamma }}$ (rad) \\
\hline \hline $1 @ 2 \mathrm{~m}$ & $1.2 \mathrm{E}+17$ & 634 & 276 \\
\hline $2 @ 2 \mathrm{~m}$ & $6.0 \mathrm{E}+16$ & 367 & 467 \\
\hline $3 @ 6 \mathrm{~m}^{\text {(a) }}$ & $2.8 \mathrm{E}+17$ & 78 & 187 \\
\hline
\end{tabular}

(a) Average of two PNADs facing the reactor.

Table 7 contains the detailed results for each PNAD for each experimental irradiation. The average total doses were $910 \mathrm{rad}, 834 \mathrm{rad}$, and 294 rad for the three experimental irradiations at the specified distance from the reactor.

Table 7. Results of Three Experimental Irradiations at the Silene Reactor

\section{Experiment 1 at $2 \mathrm{~m}$}

\begin{tabular}{|c||c|c|c|c|c||c|c||c|}
\hline \hline PNAD & Thermal & Epithermal & $\begin{array}{c}\mathbf{2} \mathbf{~ e V} \text { to } \\
\mathbf{0 . 5} \mathbf{~ M e V}\end{array}$ & $\begin{array}{c}\mathbf{>} \mathbf{1 . 2} \\
\mathbf{M e V}\end{array}$ & $\begin{array}{c}\mathbf{> 2 . 9} \\
\mathbf{M e V}\end{array}$ & $\begin{array}{c}\text { Dose } \\
\text { (rad) }\end{array}$ & $\begin{array}{c}\text { Dose }_{\text {gamma }} \\
\text { (rad) }\end{array}$ & $\begin{array}{c}\text { Total } \\
\text { Dose } \\
\text { (rad) }\end{array}$ \\
\hline \hline 1 & 3.5 & 0.016 & 68 & 490 & 47 & 608 & 214 & 822 \\
\hline 2 & 4.5 & 0.018 & 76 & 505 & 53 & 639 & 367 & 1,006 \\
\hline 3 & 3.2 & 0.015 & 69 & 579 & 49 & 701 & 277 & 978 \\
\hline 4 & 3.3 & 0.016 & 65 & 492 & 49 & 610 & 270 & 880 \\
\hline 5 & 3.1 & 0.015 & 58 & 502 & 46 & 610 & 252 & 862 \\
\hline \hline Average & 3.5 & 0.016 & 67 & 514 & 49 & 634 & 276 & 910 \\
\hline
\end{tabular}

\section{Experiment 2 (at $2 \mathrm{~m}$ )}

\begin{tabular}{|c||c|c|c|c|c||c|c||c||}
\hline PNAD & Thermal & Epithermal & $\begin{array}{c}\mathbf{2} \mathbf{~ e V} \text { to } \\
\mathbf{0 . 5} \mathbf{~ M e V}\end{array}$ & $\begin{array}{c}\mathbf{>} \mathbf{1 . 2} \\
\mathbf{M e V}\end{array}$ & $\begin{array}{c}\mathbf{> 2 . 9} \\
\mathbf{M e V}\end{array}$ & $\begin{array}{c}\text { Dose } \\
\text { (rad) }\end{array}$ & $\begin{array}{c}\text { Dose } \\
\text { (rad) }\end{array}$ & $\begin{array}{c}\text { Total } \\
\text { Dose } \\
\text { (rad) }\end{array}$ \\
\hline \hline 6 & 1.4 & 0.0064 & 29 & 281 & 42 & 353 & 413 & 766 \\
\hline 7 & 1.9 & 0.0066 & 35 & 260 & 43 & 340 & 479 & 819 \\
\hline 8 & ND & ND & 28 & 373 & 41 & 443 & 534 & 977 \\
\hline 9 & ND & ND & 24 & 198 & 44 & 266 & 467 & 733 \\
\hline 10 & 2.3 & 0.0015 & 26 & 362 & 44 & 433 & 442 & 875 \\
\hline \hline Average & 1.9 & 0.0049 & 28 & 295 & 43 & 367 & 467 & 834 \\
\hline
\end{tabular}

$\mathrm{ND}=$ No In-116m detected. 


\section{PNNL Personnel Nuclear Accident Dosimeter Results from 2009 Intercomparison Exercise at the Silene Reactor, October 2009}

Issued: June 2010

PNNL-19503

Revision: 0

Page 12 of 14

\section{Experiment $3($ at $6 \mathrm{~m})$}

\begin{tabular}{|c||c|c|c|c|c||c|c||c|}
\hline \hline PNAD $^{(\mathbf{a})}$ & Thermal & Epithermal & $\begin{array}{c}\mathbf{2} \mathbf{~ e V} \text { to } \\
\mathbf{0 . 5} \mathbf{~ M e V}\end{array}$ & $\begin{array}{c}\mathbf{>} \mathbf{1 . 2} \\
\mathbf{M e V}\end{array}$ & $\begin{array}{c}\mathbf{2} .9 \\
\mathbf{M e V}\end{array}$ & $\begin{array}{c}\text { Dose } \\
\text { (rad) }\end{array}$ & $\begin{array}{c}\text { Doutron } \\
\text { (rad) }\end{array}$ & $\begin{array}{c}\text { Total } \\
\text { Dose } \\
\text { (rad) }\end{array}$ \\
\hline \hline $11-\mathrm{F}$ & 0.94 & 0.0037 & 11 & 82 & 14 & 108 & 187 & 295 \\
\hline $12-\mathrm{F}$ & 1.00 & 0.0039 & 12 & 94 & 14 & 121 & 171 & 292 \\
\hline $13-\mathrm{S}$ & 0.50 & 0.0015 & 6.3 & 15 & 2.1 & 24 & 92 & 116 \\
\hline $14-\mathrm{S}$ & 0.50 & 0.0014 & 4.3 & 52 & 2.5 & 60 & 99 & 159 \\
\hline $15-\mathrm{B}$ & 0.79 & 0.0020 & 8.1 & 82 & 11 & 102 & 132 & 234 \\
\hline $16-\mathrm{B}$ & 0.57 & 0.0026 & 11 & 61 & 11 & 84 & 442 & 526 \\
\hline $17-\mathrm{FIA}$ & 0.61 & 0.0034 & 14 & 113 & 14 & 142 & 443 & 585 \\
\hline Average & 0.70 & 0.0026 & 10 & 71 & 10 & 78 & 187 & 265 \\
\hline
\end{tabular}

(a) $\mathrm{F}=$ Front; $\mathrm{S}=$ Side; $\mathrm{B}=$ Back of phantom; FIA = Free $\ln$ Air.

The fraction of the neutron dose that was estimated for each neutron dose range is given in Table 8.

Table 8. Fraction of Neutron Dose Contribution ${ }^{(a)}$

\begin{tabular}{|c|l|l|l|}
\hline \multirow{2}{*}{ Energy Range } & \multicolumn{3}{|c|}{ Fraction of Total Neutron Dose } \\
\cline { 2 - 4 } & \multicolumn{1}{|c|}{ Expt. 1 } & \multicolumn{1}{|c|}{ Expt. 2 } & \multicolumn{1}{c|}{ Expt. 3 } \\
\hline \hline Thermal to 0.4 eV & 0.0055 & 0.0051 & 0.0090 \\
\hline $0.4 \mathrm{eV}$ to $2 \mathrm{eV}$ & 0.000025 & 0.000013 & 0.000034 \\
\hline 2 eV to 0.5 MeV & 0.106 & 0.077 & 0.12 \\
\hline$>1.2 \mathrm{MeV}$ & 0.81 & 0.80 & 0.91 \\
\hline$>2.9 \mathrm{MeV}$ & 0.077 & 0.12 & 0.13 \\
\hline
\end{tabular}

(a) Based on the average of PNAD measurements where rounding errors may apply.

\subsection{DISCUSSION}

The Hanford PNAD was tested using experimental irradiations at the Silene reactor at the CEA Valduc Center. The Valduc Staff provided their results on number of calculated fissions per irradiation, and the $D_{\text {neutron }}$ and $D_{\text {gamma }}$ data for each irradiation at $2,3,4$, and $6 \mathrm{~m}$. The number of fissions for Valduc and PNNL are given in Table 9. The Valduc reference dose results are summarized in Table 10 as they pertain to the Hanford experimental setup. The calculated neutron doses from the Hanford PNAD are in good agreement with the Valduc reference values. The Hanford PNAD gamma doses were also in good agreement with the reference values, except for Experiment 1. Further analysis of the gamma doses from the TLD chips in the PNADs and other dosimeters used is needed. 


\section{PNNL Personnel Nuclear Accident Dosimeter Results from 2009 Intercomparison Exercise at the Silene Reactor, October 2009}

Table 9. Number of Fissions For Each Irradiation Experiment

\begin{tabular}{||c||c|c|c||}
\hline Expt. & Reference \# Fissions & $\begin{array}{c}\text { PNNL Estimated } \\
\text { \# Fissions }\end{array}$ & Difference \\
\hline \hline $1 @ 2 \mathrm{~m}$ & $1.8 \mathrm{E}+17$ & $1.2 \mathrm{E}+17$ & $-31 \%$ \\
\hline $2 @ 2 \mathrm{~m}$ & $6.3 \mathrm{E}+16$ & $6.0 \mathrm{E}+16$ & $-4 \%$ \\
\hline $3 @ 6 \mathrm{~m}^{\text {(a) }}$ & $1.9 \mathrm{E}+17$ & $2.8 \mathrm{E}+17$ & $45 \%$ \\
\hline
\end{tabular}

(a) Average of two PNADs facing the reactor.

Table 10. Average Neutron to Gamma Dose Ratios ${ }^{(a)}$

\begin{tabular}{|c|c|c|c|c|c|c|c|c|c|}
\hline \multirow{2}{*}{ Expt. } & \multicolumn{3}{|c|}{$\begin{array}{c}\text { Reported Reference Dose } \\
\text { Information }^{(\mathrm{b})}\end{array}$} & \multicolumn{3}{|c|}{ PNNL PNAD Dose Information } & \multicolumn{3}{|c|}{ Difference } \\
\hline & $\begin{array}{l}\text { Dose }_{\text {neutron }} \\
\text { (rad) }\end{array}$ & $\begin{array}{l}\text { Dose }_{\text {gamma }} \\
\text { (rad) }\end{array}$ & $\begin{array}{c}\mathrm{n} / \mathrm{g} \\
\text { Ratio }\end{array}$ & $\begin{array}{l}\text { Dose }_{\text {neutron }} \\
\text { (rad) }\end{array}$ & $\begin{array}{l}\text { Dose }_{\text {gamma }} \\
\text { (rad) }\end{array}$ & $\begin{array}{c}\mathrm{n} / \mathrm{g} \\
\text { Ratio }\end{array}$ & $\mathbf{n}$ & g & $\mathrm{n} / \mathrm{g}$ \\
\hline $1 @ 2 m$ & 690 & 50 & 13.8 & 633 & 276 & 2.30 & $8.2 \%$ & $452 \%$ & $83 \%$ \\
\hline $2 @ 2$ m & 320 & 380 & 0.8 & 367 & 467 & 0.79 & $14 \%$ & $23 \%$ & $6.7 \%$ \\
\hline $3 @ 6 m$ & 153 & 210 & 0.8 & 78 & 187 & 0.42 & $-23 \%$ & $-15 \%$ & $9.7 \%$ \\
\hline
\end{tabular}

(a) For PNADS on the front of the phantom only.

(b) From French reports, CEA/VA/DRMN/SRNC DO 1076, 1077, and 1078.

The preliminary ratios of the average neutron dose compared to the front-facing PNADs are given in Table 11. For the three different dosimeter orientations used in Experiment 3, more evaluation and consideration is needed. The slight changes in orientation may have large impacts on the resultant data.

Table 11. Preliminary PNAD Neutron Dose Related to Orientation ${ }^{(a)}$

\begin{tabular}{|c|c|}
\hline $\begin{array}{c}\text { Dosimeter } \\
\text { Orientation }^{(\mathbf{b})}\end{array}$ & $\begin{array}{c}\text { Ratio to Front } \\
\text { Facing PNAD }\end{array}$ \\
\hline \hline Front & 1.0 \\
\hline Side & 0.36 \\
\hline Back & 0.81 \\
\hline
\end{tabular}

\subsection{ACKNOWLEDGEMENTS}

The authors wish to thank Jerry McKamy and Jim Felty of the U.S. Department of Energy Nuclear Criticality Safety Program for financial support in order that we could participant in this intercomparison study. We wish to also thank Bruce Rathbone, Chandy Lindberg, and Randy Berg for getting the test version of the PNAD designed and made to specifications in short order and providing analysis of the PNAD TLD chips; Dave Heinrichs, Dave Hickman, and Carolyn Wong at LLNL for setting up the DOE Laboratory participation in the Valduc exercises and providing timely onsite counting of the foils and sulfur tablets; and to the CEA Valduc staff, without whose efforts and cooperation this work would not have been possible. Their staff were all most gracious and accommodating to our needs. 
PNNL Personnel Nuclear Accident Dosimeter Results from 2009 Intercomparison Exercise at the Silene Reactor, October 2009

Issued: June 2010

PNNL-19503

Revision: 0

Page 14 of 14

\subsection{REFERENCES}

CEA/VA/DRMN/SRNC DO 1077. December 2009. Silene Intercomparison - Experiment S1677 on October 13, 2009.

CEA/VA/DRMN/SRNC DO 1078. December 2009. Silene Intercomparison - Experiment S2677 on October 14, 2009.

CEA/VA/DRMN/SRNC DO 1076. December 2009. Silene Intercomparison - Experiment S3677 on October 15, 2009.

PNNL. 2010. Hanford External Dosimetry Technical Basis Manual, PNL-MA-842. Pacific Northwest National Laboratory, Richland, Washington. 